\title{
Localization of the Cell-associated Phosphatase in Lysobacter enzymogenes
}

\author{
By RICHARD G. VON TIGERSTROM* AND SHEILAH STELMASCHUK \\ Department of Microbiology, University of Alberta, Edmonton, Alberta, Canada T6G 2E9
}

(Received 22 October 1984)

\begin{abstract}
In addition to an excreted phosphatase, Lysobacter enzymogenes produces a distinctly different alkaline phosphatase which remains associated with the cells. It is the only major phosphatase contained in the cells. Little enzyme activity is found in whole cells using the standard assay with $p$-nitrophenyl phosphate as the substrate, but maximum activity can be obtained after toluene or detergent treatment, or mechanical disruption of the cells. The phosphatase is not released from the cells by osmotic shock, or by treatment with $\mathrm{MgCl}_{2}$ or high $\mathrm{LiCl}$ concentrations. It is associated with the particulate fraction in cell-free extracts and detergents solubilize the enzyme from intact and broken cells. Separation of the inner and outer membranes of the cells by sucrose gradient centrifugation showed that most, if not all, of this phosphatase is located in the outer membrane.
\end{abstract}

\section{INTRODUCTION}

Lysobacter enzymogenes is a Gram negative, non-fruiting gliding bacterium of the class Flexibacteriae (Reichenbach, 1981). It produces a number of extracellular enzymes and is thought to play an active role in biodegradation (Christensen \& Cook, 1978; Reichenbach \& Dworkin, 1981). Enzymes such as proteases (Whitaker, 1970), nucleases (von Tigerstrom, 1980, 1981), chitinase (Christensen \& Cook, 1978), a phosphatase (von Tigerstrom, 1980) and other proteins are excreted into the medium. It was thought, initially, that the organism produces one phosphatase and that most of this enzyme is excreted. However, subsequent studies showed that L. enzymogenes produces two different phosphatases and that one is excreted into the medium and the other remains associated with the cells (von Tigerstrom, 1983, 1984). The excreted enzyme has been purified and characterized (von Tigerstrom, 1984). It is most active at $\mathrm{pH} 7 \cdot 5$, is not inhibited by EDTA or other chelating agents and has a molecular weight of about 25000 . Preliminary studies on the cell-associated phosphatase showed that it is most active at $\mathrm{pH} 8 \cdot 5$, is strongly inhibited by EDTA but can be reactivated to some extent by the addition of $\mathrm{Zn}^{2+}$ and has a molecular weight much greater than 25000 (von Tigerstrom, 1984). Thus, the two enzymes can be clearly distinguished.

The association of proteins with different regions of the envelope has been investigated in Escherichia coli and other Gram negative organisms (Osborn \& Wu, 1980; Silhavy et al., 1983; Lugtenberg \& Van Alphen, 1983). Techniques have been established to determine whether a protein is associated with the cell membrane, the periplasm or the outer membrane of the cell envelope. Hydrolytic enzymes are most frequently found in the periplasm, especially in $E$. coli, and they may be released from this compartment by osmotic shock or the preparation of spheroplasts (Neu \& Heppel, 1965). The existence of a number of proteins in the outer membrane has been firmly established (Osborn \& Wu, 1980; Silhavy et al., 1983; Lugtenberg \& Van Alphen, 1983), but relatively few of these proteins are known to have hydrolytic or other enzymic activities (Lugtenberg \& Van Alphen, 1983).

This paper describes some general properties of the cell-associated phosphatase of $L$. enzymogenes and the localization of this enzyme within the cell envelope.

Abbreviations: G-6-PDH, glucose-6-phosphate dehydrogenase; KDO, 2-keto-3-deoxyoctanoate. 


\section{METHODS}

Organism and culture conditions. Lysohacter enzymogenes UASM 495 (ATCC 2987) was obtained from Dr F. D. Cook, University of Alberta, Canada. It was maintained by freeze-drying and by subculturing at $25{ }^{\circ} \mathrm{C}$ on $0.2 \%$ $(\mathrm{w} / \mathrm{v})$ tryptone, $1 \%(\mathrm{w} / \mathrm{v})$ skim milk, $1.7 \%(\mathrm{w} / \mathrm{v})$ agar and storage at $4{ }^{\circ} \mathrm{C}$. Liquid cultures were grown in $0.8 \%(\mathrm{w} / \mathrm{v})$ tryptone as previously described (von Tigerstrom, 1983). They were harvested by centrifugation ( $16300 \mathrm{~g}$ for $15 \mathrm{~min}$ at $4{ }^{\circ} \mathrm{C}$ ) in the stationary phase of growth if maximum enzyme production was desired, or in the late exponéntial phase.

Enzyme assays and preparation of cell extract. The phosphatase assays, the treatment of whole cells with toluene or detergent (von Tigerstrom, 1984) and the preparation of the cell-free extract (von Tigerstrom, 1980) have been described. The enzyme preparation was diluted with $10 \mathrm{~mm}-\mathrm{Tris} / \mathrm{HCl}, 50 \mathrm{~mm}-\mathrm{NaCl}, 1.5 \mathrm{mM}-\mathrm{MgCl}_{2}, \mathrm{pH} 7.4$ for routine assays. NADH oxidase was assayed as described by Osborn et al. (1972) and glucose-6-phosphate dehydrogenase (G-6-PDH) was determined with NAD as the coenzyme according to DeMoss (1955). One unit (U) of enzyme is the amount which catalyses the formation of one $\mu$ mol product min $^{-1}$.

Preparation of shock fluids and spheroplasts. For these procedures the cells were harvested before the stationary phase, usually at $\mathrm{OD}_{600}=2$. The cold osmotic shock procedure was essentially that of Neu \& Heppel (1965) with some modifications (von Tigerstrom, 1983). In addition, intact cells were treated with $\mathrm{MgCl}_{2}$ solutions (Cheng et al., 1970a). The cells were harvested and washed by resuspension in $10 \mathrm{~mm}-$ Tris $/ \mathrm{HCl}, 50 \mathrm{~mm}-\mathrm{NaCl}, 1.5 \mathrm{~mm}-$ $\mathrm{MgCl}_{2}, \mathrm{pH} 7 \cdot 4$. They were suspended to the original culture volume in $10 \mathrm{~mm}-\mathrm{Tris} / \mathrm{HCl}, 0 \cdot 2 \mathrm{M}-\mathrm{MgCl}_{2}, \mathrm{pH} 8 \cdot 4$ and incubated at $22^{\circ} \mathrm{C}$ for $15 \mathrm{~min}$ with shaking at 150 r.p.m. The supernatant obtained after centrifugation at $12000 \mathrm{~g}$ for $10 \mathrm{~min}$ was termed the ' $\mathrm{MgCl}_{2}$ extract'. The cells were suspended in $10 \mathrm{~mm}$-Tris/ $\mathrm{HCl}, 10 \mathrm{mM}-\mathrm{MgCl}_{2}, \mathrm{pH} \mathrm{8.4}$, incubated and centrifuged as before to yield the $\mathrm{MgCl}_{2}$ shock fluid and the treated cells. The $\mathrm{MgCl}_{2}$ extract, the $\mathrm{MgCl}_{2}$ shock fluid and the treated cells were assayed for alkaline phosphatase activity. The $\mathrm{MgCl}_{2}$ extract and the $\mathrm{MgCl}_{2}$ shock fluid were also dialysed at $0{ }^{\circ} \mathrm{C}$ against $10 \mathrm{mM}-\mathrm{Tris} / \mathrm{HCl}$; the retentate was concentrated 50 -fold by freeze-drying, dialysed again and used for 2-keto-3-deoxyoctanoate (KDO) determinations and SDS-PAGE.

The preparation of spheroplasts was attempted according to the methods of Osborn et al. (1972) and of Cheng et al. $(1970 \mathrm{~b})$ using a $20 \%(\mathrm{w} / \mathrm{v})$ sucrose or a $0.2 \mathrm{M}-\mathrm{MgCl}_{2}$ solution as the stabilizer.

Differential centrifugation. The cell-free extract was centrifuged at $48000 \mathrm{~g}$ for $30 \mathrm{~min}$ and the resultant supernatant was centrifuged at $105000 \mathrm{~g}$ for $60 \mathrm{~min}$. The pellets were suspended in $10 \mathrm{~mm}-\mathrm{Tris} / \mathrm{HCl}, 50 \mathrm{~mm}-\mathrm{NaCl}$, $1.5 \mathrm{mM}-\mathrm{MgCl}_{2}, \mathrm{pH} \mathrm{7.4}$. Phosphatase and G-6-PDH activities were determined in the supernatants and in the suspended pellets.

Separation of cell wall components. The method was based on the procedure of Hancock \& Nikaido (1978). Cells from a $400 \mathrm{ml}$ culture with an $\mathrm{OD}_{600}$ of 2.08 were washed by suspension and centrifugation in $40 \mathrm{ml} 8 \mathrm{~mm}-$ Tris $/ \mathrm{HCl}$, pH 7.8. They were suspended in $34 \mathrm{ml} \mathrm{10 \% (w/v)} \mathrm{sucrose,} 8 \mathrm{~mm}$-Tris/ $\mathrm{HCl}$, pH 7.8. DNAase I and RNAase A were each added to $50 \mu \mathrm{g} \mathrm{ml}^{-1}$ and the suspension was passed twice through a French pressure cell (103.4 MPa) at $5^{\circ} \mathrm{C}$. When indicated, lysozyme was added to $0.2 \mathrm{mg} \mathrm{ml}^{-1}$ and the homogenate from the pressure cell was incubated at $22^{\circ} \mathrm{C}$ for $30 \mathrm{~min}$. Intact cells were removed by centrifugation at $2000 \mathrm{~g}$ for $15 \mathrm{~min}$. The resultant cell extract was placed $(5.5 \mathrm{ml}$ per tube) on a step gradient of $0.5 \mathrm{ml} 72 \%(\mathrm{w} / \mathrm{v})$ sucrose, $8 \mathrm{mM}-\mathrm{Tris} / \mathrm{HCl}$, $\mathrm{pH} 7.8$ and $5.5 \mathrm{ml} 15 \%(\mathrm{w} / \mathrm{v})$ sucrose, $8 \mathrm{~mm}-\mathrm{Tris} / \mathrm{HCl}, \mathrm{pH} 7.8$. The tubes were centrifuged in a Beckman SW $40 \mathrm{Ti}$ rotor at 35000 r.p.m. for $90 \mathrm{~min}$ at $2{ }^{\circ} \mathrm{C}$. The bottom $1.6 \mathrm{ml}$ from each tube was removed and diluted with $0.4 \mathrm{ml}$ $8 \mathrm{mM}$-Tris $/ \mathrm{HCl}, \mathrm{pH} 7.8$. Approximately $1.6-1.8 \mathrm{ml}$ of this preparation was placed on a sucrose gradient consisting of $1 \mathrm{ml} 72 \%(\mathrm{w} / \mathrm{v})$ sucrose, $8 \mathrm{~mm}$-Tris $/ \mathrm{HCl}, \mathrm{pH} 7.8$, and $1.9 \mathrm{ml}$ each of $60 \%, 55 \%, 50 \%, 45 \%$ and $40 \%(\mathrm{w} / \mathrm{v})$ sucrose, $8 \mathrm{~mm}$-Tris/ $\mathrm{HCl}, \mathrm{pH} 7 \cdot 8$. The gradients were stored at $4{ }^{\circ} \mathrm{C}$ for $24-28 \mathrm{~h}$ before use to give a linear sucrose gradient above the $72 \%(\mathrm{w} / \mathrm{v})$ sucrose cushion; the subsequent centrifugation was at $30000 \mathrm{r} . \mathrm{p} . \mathrm{m}$. in a SW $40 \mathrm{Ti}$ rotor at $2{ }^{\circ} \mathrm{C}$ for $19 \mathrm{~h}$. The gradient fractions were analysed for $\mathrm{NADH}$ oxidase and alkaline phosphatase activities, and the $A_{280}$ measured. The contents of several tubes were pooled for further analysis as indicated below.

$P A G E$. This was done in $1.5 \times 140 \times 160 \mathrm{~mm}$ slabs of $10 \%$ acrylamide gel containing $0.1 \%$ SDS (Maizel, 1971 ). The samples were treated with $1 \%$ SDS, $0 \cdot 1 \% 2$-mercaptoethanol and heated for $10 \mathrm{~min}$ in a boiling water bath. To retain phosphatase activity, 2-mercaptoethanol and the heat treatment were omitted. The gels were treated with Coomassie blue to stain protein (Fairbanks et al., 1971). The molecular mass markers used were phosphorylase $b$ (97 kDal), bovine serum albumin (67 kDal), ovalbumin ( $45 \mathrm{kDal})$, chymotrypsinogen $\mathrm{A}$ ( $25 \mathrm{kDal})$ and cytochrome $c(12.5 \mathrm{kDal})$. All protein standards were from Pierce Chemical Co. (Rockford, Ill., USA), except for phosphorylase $b$ which was from Sigma. A solution of $0.5 \mathrm{M}-\mathrm{Tris} / \mathrm{HCl}, 1 \mathrm{mM}-\mathrm{MgCl}_{2}, 0 \cdot 1 \mathrm{mM}-\mathrm{ZnCl}, 2 \%(\mathrm{v} / \mathrm{v})$ Triton X-100, 0.125 mg $\alpha$-naphthyl acid phosphate $\mathrm{ml}^{-1}, 0.2 \mathrm{mg}$ Fast Blue BB ml $\mathrm{m}^{-1}, \mathrm{pH} 8 \cdot 5$, at $22^{\circ} \mathrm{C}$ was used to stain for alkaline phosphatase activity in the gels. The activity stains were fixed with $10 \%(\mathrm{v} / \mathrm{v})$ acetic acid.

Analytical. Protein was assayed by the Lowry method; KDO and poly- $\beta$-hydroxybutyrate were assayed by the methods of Osborn et al. (1972) and Law \& Slepecky (1971) respectively. All spectrophotometric measurements were made with a Perkin Elmer Lambda 3 UV/VIS spectrophotometer. 


\title{
Table 1. Differential centrifugation of L. enzymogenes cell-free extract
}

\begin{abstract}
Cell-free extract $(10 \mathrm{ml})$ was centrifuged as described in Methods and the different fractions were assayed for phosphatase and G-6-PDH activities. Values for phosphatase are from a representative experiment $; 72-78 \%$ of this enzyme was routinely recovered in the $48000 \mathrm{~g}$ pellet. The determination of G-6-PDH was done twice; the results given are representative of these two experiments.
\end{abstract}

\begin{tabular}{lcc}
\multicolumn{1}{c}{ Fraction } & $\begin{array}{c}\text { Phosphatase } \\
\text { (U) }\end{array}$ & G-6-PDH \\
Cell-free extract & 8.53 & (U) \\
$48000 \mathrm{~g}$ supernatant & 1.69 & 0.36 \\
$48000 \mathrm{~g}$ pellet & 6.49 & 0.37 \\
$105000 \mathrm{~g}$ supernatant & 0.91 & 0 \\
$105000 \mathrm{~g}$ pellet & 0.65 & $0 \cdot 31$ \\
\end{tabular}

\section{RESULTS AND DISCUSSION}

The excreted phosphatase of $L$. enzymogenes can be clearly distinguished from the cellassociated enzyme. The phosphatase activity in cell-free extracts is inhibited more than $99 \%$ by 5 mM-EDTA. Since the excreted enzyme is insensitive to EDTA (von Tigerstrom, 1984) it does not contribute to the cell-associated activity. It was also established that the cell-associated enzyme is not excreted to any extent, even during the stationary growth phase of the organism, since the phosphatase activity in the culture supernatant was not inhibited by EDTA.

It was important to determine whether there was more than one cell-associated phosphatase. Several observations indicated that the cells do not contain an acid phosphatase and only contain one major cell-associated phosphatase. The relative activities at different $\mathrm{pH}$ values from $\mathrm{pH} 4$ to $\mathrm{pH} 10$ were determined with a crude cell extract and with an 18-fold purified phosphatase preparation, and they were found to be nearly identical, with a maximum activity at $\mathrm{pH}$ 8.5. As will be shown below, PAGE of crude cell-free extracts revealed only one band of phosphatase activity. Similarly, ion-exchange chromatography revealed only one peak of activity.

When whole cells were used for the assay, less than $5 \%$ of the total phosphatase was detected. Complete expression of the activity was obtained by toluene treatment of the cells, by treatment with detergents such as Zwittergent 3-14, Triton $\mathrm{X}-100$ or deoxycholate at $37^{\circ} \mathrm{C}$, or by disruption of the cells with the French pressure cell. Detergents, especially Zwittergent 3-14 and deoxycholate, solubilized the enzyme from intact and broken cells, whereas toluene treatment of the cells only provided access of the substrate to the enzyme. Addition of detergents to mechanically disrupted cells did not enhance the activity.

Several experiments were done to learn more about the association of the phosphatase with the cells. In many bacteria, phosphatases are present in the cell envelope. In $E$. coli the alkaline phosphatases and a number of other enzymes can be readily released by preparing spheroplasts and by osmotic shock (Neu \& Heppel, 1965). Attempts to prepare spheroplasts of $L$. enzymogenes were unsuccessful regardless of whether the lysozyme treatment was done with or without EDTA, or with sucrose or $\mathrm{MgCl}_{2}$ as the stabilizing agent. A few cells seemed to be converted to spheroplast-like bodies in $20 \%(\mathrm{w} / \mathrm{v})$ sucrose, $0.5 \mathrm{mg}$ lysozyme $\mathrm{ml}^{-1}$, but only $5 \%$ of the phosphatase was removed from the cells. Cold osmotic shock of L. enzymogenes released only $8 \%$ of the phosphatase.

Similarly, a $\mathrm{MgCl}_{2}$ treatment of the cells, which causes quantitative release of the phosphatase from Pseudomonas aeruginosa (Cheng et al., 1970a), did not remove the enzyme from $L$. enzymogenes. Taking activity in a cell lysate as $100 \%$, some $90 \%$ of the total activity remained associated with the cells after $\mathrm{MgCl}_{2}$ treatment; less than $1 \%$ was found in the $\mathrm{MgCl}_{2}$ extract, and only $4.6 \%$ in the $\mathrm{MgCl}_{2}$ shock fluid. However, some other proteins were specifically released by $\mathrm{MgCl}_{2}$ treatment as indicated below although little or no $\mathrm{KDO}$ was removed from the cells. High concentrations of $\mathrm{LiCl}$ (Pooley et al., 1970) also failed to release the phosphatase.

The particulate nature of the phosphatase was clearly shown after differential centrifugation of a cell-free extract (Table 1). As expected, the soluble marker enzyme, G-6-PDH, was not 


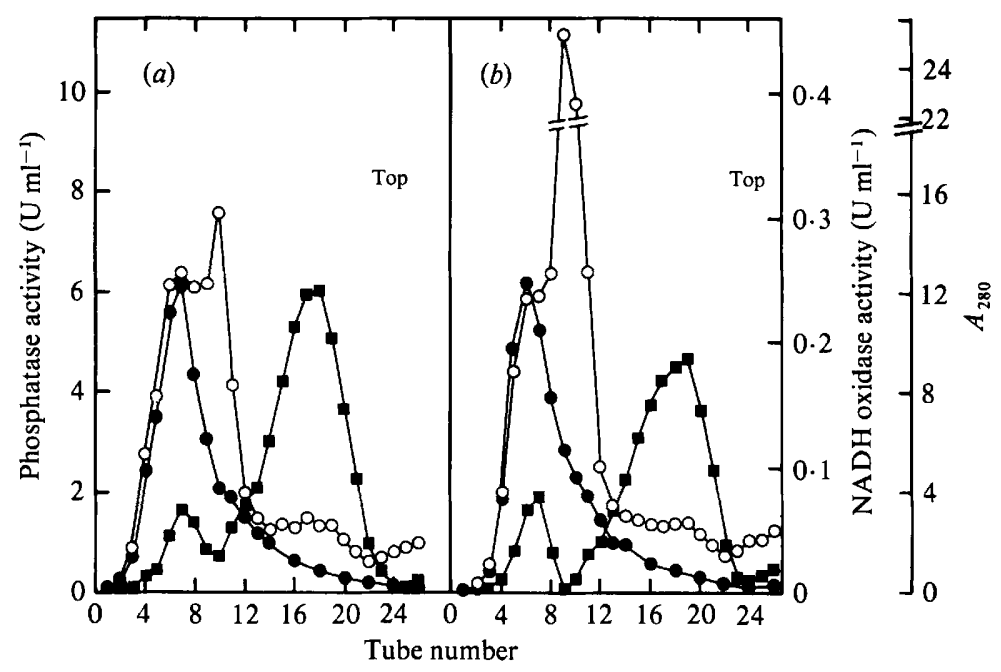

Fig. 1. Separation of inner and outer membranes by sucrose gradient centrifugation. The separation was done as described in Methods with lysozyme treatment $(a)$ and without lysozyme treatment $(b)$. The phosphatase (O), the NADH oxidase activities $(\square)$ and the $A_{280}(O)$ were determined. The separation of the inner and outer membranes has been achieved in five separate experiments; the latter three experiments varied only with respect to the sucrose gradient composition which was adjusted to obtain the best separation of the outer membrane and the poly- $\beta$-hydroxybutyrate peak. The values obtained varied slightly from one experiment to the next but the general pattern and the relative amounts in each fraction were very similar (see also Table 2).

Table 2. Enzymic and chemical analysis of L. enzymogenes membrane fractions

These values were obtained in the experiment shown in Fig. 1(a).

$\begin{array}{ccccc}\text { Fraction } & \begin{array}{c}\text { Phosphatase } \\ \left(\mathrm{U} \mathrm{ml}^{-1}\right)\end{array} & \begin{array}{c}\text { NADH } \\ \text { oxidase } \\ \left(\mathrm{U} \mathrm{ml}^{-1}\right)\end{array} & \begin{array}{c}\text { Protein } \\ \left(\mathrm{mg} \mathrm{ml}^{-1}\right)\end{array} & \begin{array}{c}\mathrm{KDO} \\ \left(\mu \mathrm{g} \mathrm{ml}^{-1}\right)\end{array} \\ \text { OM1 } & 4.37 & 0.038 & 0.80 & 4.20 \\ \text { OM2 } & 2 \cdot 11 & 0.044 & 0.70 & 1.50 \\ \text { IM } & 0.36 & 0.188 & 0.45 & 0.35\end{array}$

sedimented at $48000 \mathrm{~g}$ and only $12 \%$ was associated with the $105000 \mathrm{~g}$ pellet. In contrast, $83 \%$ of the phosphatase was sedimented, and most of this $(76 \%)$ was in the $48000 \mathrm{~g}$ pellet, which would contain membranes and cell wall fragments. These results indicate that the phosphatase is not free in the periplasm, and that it is probably associated with the particulate envelope fraction of the bacteria by hydrophobic, rather than ionic, interaction.

To determine the location of the enzyme within the cell envelope, the inner (cytoplasmic) and outer membranes of $L$. enzymogenes were separated by isopycnic centrifugation on sucrose gradients as described in Methods. Figs $1(a)$ and $1(b)$ show the separations obtained with and without lysozyme treatment of the cell-free extracts. The profiles are very similar, indicating that lysozyme treatment is not required for the successful separation of the cell envelope components from L. enzymogenes. The gradient profiles were divided into three fractions: OM1, tubes 4-8; OM2, tubes 9-12; and IM, tubes 16-21. These tubes were subjected to further analysis. The enzyme activities, protein and KDO concentrations are listed in Table 2 and the separation of the proteins by PAGE is shown in Figs 2 and 3.

NADH oxidase was used as a marker enzyme for the cytoplasmic membrane and Table 2 shows that the cytoplasmic and outer membranes have been separated, although some NADH oxidase appears to contaminate the outer membrane fraction. This contamination is probably due to non-specific association of NADH oxidase with outer membrane components during the $30 \mathrm{~min}$ incubation of the extract before the sucrose gradient separation. This association 


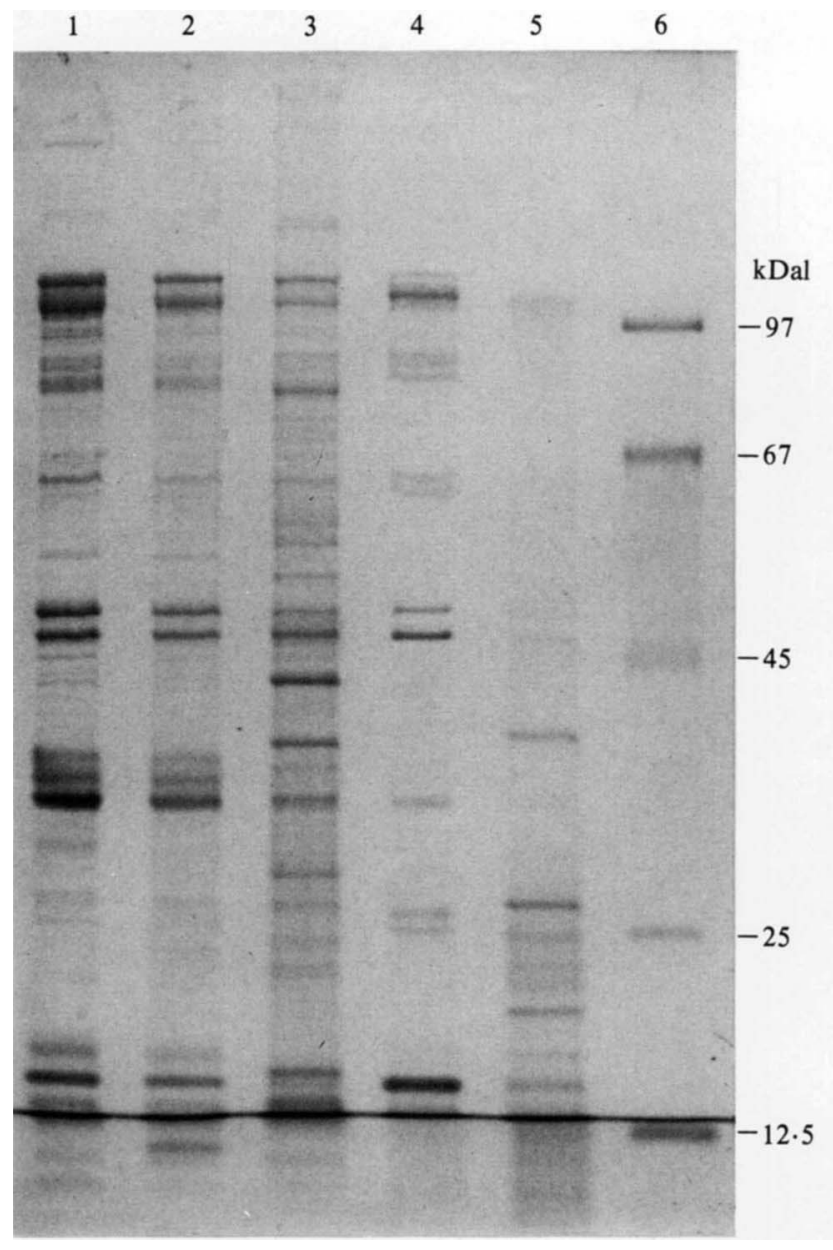

Fig. 2. SDS-PAGE of cell envelope proteins. The samples and the amounts of protein applied to each lane were: (1) $20 \mu \mathrm{g} \mathrm{OM1} \mathrm{;} \mathrm{(2)} 18 \mu \mathrm{g}$ OM2 ; (3) $18 \mu \mathrm{g} \mathrm{IM}$; (4) $12 \mu \mathrm{g} \mathrm{MgCl}_{2}$ extract ; (5) $11 \mu \mathrm{g} \mathrm{MgCl}_{2}$ shock fluid. Lane (6) contained the five standard proteins (see Methods).

appears to be temperature-dependent since the contamination was greatly increased when the incubation was carried out at $37^{\circ} \mathrm{C}$, the maximum growth temperature for L. enzymogenes. The phosphatase was associated primarily with the densest component in the gradient and this also contained the highest KDO concentration. Therefore, the phosphatase is associated with the outer membrane of $L$. enzymogenes. The $A_{280}$ values given in Fig. 1 for fractions 4-12 are largely due to turbidity. The peak at tube 10 (Fig. $1 a$ ) and tube 9 (Fig. $1 b$ ) coincided with a whitish band in the gradient and the amount of material in it varied significantly from experiment to experiment. This material is most likely to be poly- $\beta$-hydroxybutyrate, which we have found to be present in this organism.

Fig. 2 shows the electrophoretic separation of the proteins from fractions OM1, OM2 and IM recovered from the sucrose gradient of Fig. $1(a)$, and from the $\mathrm{MgCl}_{2}$ extract and shock fluid. The samples put on the gel were all treated with SDS, 2-mercaptoethanol and heat. Ten to twelve major proteins were present in fraction OM1. Corresponding bands, although less intense, were present in fraction OM2. The cytoplasmic membrane fraction (IM) contained few unique major protein bands but a large number of minor ones. Some of these may be due to contamination from the outer membrane, however. The $\mathrm{MgCl}_{2}$ extract and the $\mathrm{MgCl}_{2}$ shock fluid contained proteins which appear to be major outer membrane proteins. 


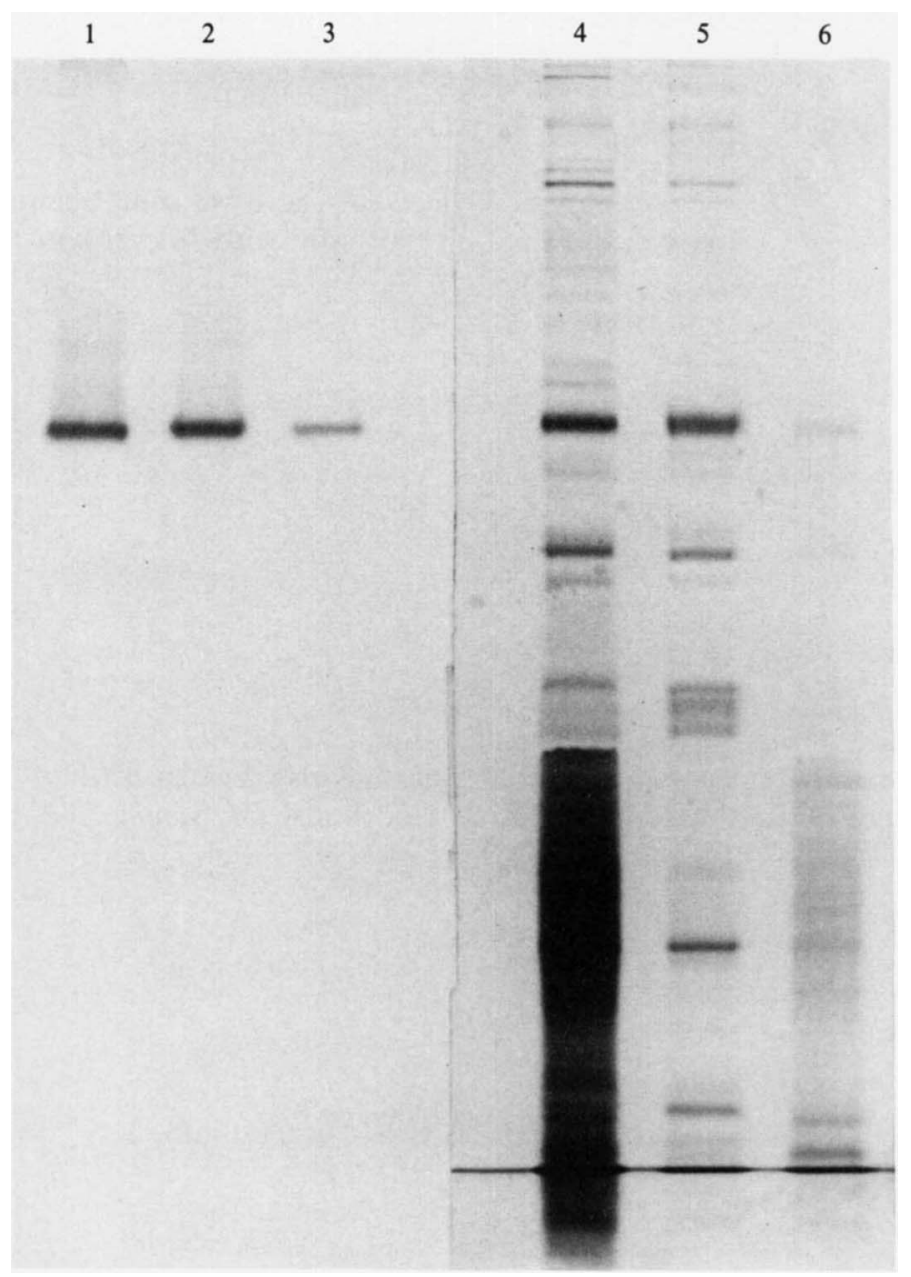

Fig. 3. PAGE of samples containing active alkaline phosphatase. Electrophoresis was done in the presence of SDS, but 2-mercaptoethanol was not added and the heat treatment was omitted. The samples and the amounts of protein in each lane were: (1) and (4), $92 \mu \mathrm{g}$ cell-free extract; (2) and (5), $24 \mu \mathrm{g} \mathrm{OM} 1$; and (3) and (6) $18 \mu \mathrm{g}$ IM. Lanes (1), (2) and (3) were stained for phosphatase activity and lanes (4), (5) and (6) for protein. The electrophoretic mobilities of the major protein bands and the phosphatase band in this figure and in Fig. 2 were reproducible from experiment to experiment.

We were unable to reactivate the phosphatase after heating in the presence of SDS. Therefore, a modified procedure was used to obtain enzyme activity after SDS-PAGE. All samples put on to the gel were previously treated with $1 \%$ SDS but not with 2 -mercaptoethanol and heat. Fig. 3 shows the electrophoretic separation of the cell-free extract, OMI and IM proteins. The samples were applied in duplicate so that both activity staining and protein staining could be carried out.

A single heavy band of phosphatase activity was found in the cell-free extract and the outer membrane sample, and a single minor band in the cytoplasmic membrane fraction. Good separation of the proteins was obtained and the phosphatase activity appeared to coincide with one of the major protein bands. As expected, the separation of the proteins of the outer and cytoplasmic membranes was quite different when the samples were not heated with 2mercaptoethanol (Fig. 3 compared to Fig. 2).

Approximately $60 \%$ of the cell-associated phosphatase could routinely be recovered in the outer membrane fractions. The remainder was discarded with the supernatant of the 
preliminary sucrose gradient centrifugation. It was probably associated with small membrane fragments. Since there was no evidence for more than one phosphatase most, if not all, of the cell-associated phosphatase is located in the outer membrane of L. enzymogenes.

The method used to isolate membrane components was a modification of that reported by Hancock \& Nikaido (1978) for Pseudomonas aeruginosa. There was some doubt as to whether a method used for a different organism would be successful with $L$. enzymogenes since its cell surface is very convoluted (unpublished observations), and the cell envelopes of gliding bacteria might be expected to differ from those of non-gliding organisms. The relatively large number of proteins in the outer membrane of $L$. enzymogenes is a major difference between this organism and $\boldsymbol{P}$. aeruginosa. The separation of the outer and inner membranes was unlike that reported for Myxococcus xanthus, another gliding bacterium, which has an outer membrane which is less dense than the inner membrane (Orndorff \& Dworkin, 1980).

The cell-associated phosphatase of L. enzymogenes is a hydrophobic protein and is probably associated with the outer membrane components by hydrophobic interaction. This is an unusual location for alkaline phosphatase in Gram negative organisms. Generally the outer membrane has little enzyme activity, although the presence of a few enzymes such as phospholipase and a protease has been firmly established and some may be located there temporarily while being excreted (Lugtenberg \& Van Alphen, 1983). In Capnocytophaga spp., anaerobic gliding bacteria, a large proportion of the acid and alkaline phosphatases are associated with the outer membrane. Substantial amounts of these enzymes are also located in the periplasm and in membrane vesicles (Poirier \& Holt, 1983a, b). In contrast, $M$. xanthus has a cell-associated phosphatase which has been reported to be present on the external surface of the cytoplasmic membrane and in the periplasm (Voelz \& Ortigoza, 1968), and in Cytophaga johnsonae, also a gliding organism, the phosphatase is cell-associated but readily solubilized upon cell disruption. It is probably a periplasmic enzyme. Similarly, in $E$. coli the alkaline phosphatase and other hydrolases are periplasmic in nature (Neu \& Heppel, 1965). The phosphatase in P. aeruginosa is a hydrophilic protein and it seems to interact with the outer membrane by ionic forces (Cheng $e t$ $a l ., 1970 a$ ). The enzyme is thought to be attached to the inside of the outer membrane, but, depending on culture conditions, a large proportion of the enzyme may be excreted into the medium (Ingram et al., 1973; Poole \& Hancock, 1983).

The localization of extracellular enzymes in the cell envelope, especially in the outer membrane, is poorly understood (Silhavy et al., 1983; Lugtenberg \& Van Alphen, 1983). Therefore, further study of the chemical and physical properties of the cell-associated phosphatase of $L$. enzymogenes, its interaction with outer membrane components, and how it compares with periplasmic enzymes of related organisms and with the excreted $L$. enzymogenes phosphatase, may contribute to a better understanding of protein localization and of transport through the outer membrane of Gram negative organisms.

This work was supported by the Natural Sciences and Engineering Research Council of Canada.

\section{REFERENCES}

Cheng, K.-J., Ingram, J. M. \& Costerston, J. W. $(1970 a)$. Release of alkaline phosphatase from cells of Pseudomonas aeruginosa by manipulation of cation concentration and of $\mathrm{pH}$. Journal of Bacteriology 104, $748-753$.

Cheng, K.-J., Ingram, J. M. \& Costerston, J. W. $(1970 \mathrm{~b})$. Alkaline phosphatase localization and sphaeroplast formation of Pseudomonas aeruginosa. Canadian Journal of Microbiology 16, 1319-1324.

Christensen, P. \& CoOK, F. D. (1978). Lysobacter, a new genus of non-fruiting gliding bacteria with a high base ratio. International Journal of Systematic Bacteriology 28, 367-393.
DEMoss, R. D. (1955). Glucose-6-phosphate and 6phosphogluconic dehydrogenase from Leuconostoc mesenteroides. Methods in Enzymology 1, 328334.

Fairbanks, G., Steck, T. L. \& Wallach, D. F. H. (1971). Electrophoretic analysis of major polypeptides of the human erythrocytic membrane. Biochemistry 10, 2606-2616.

HaNCOCK, R. E. W. \& Nikaido, H. (1978). Outer membranes of gram-negative bacteria, XIX. Isolation from Pseudomonas aeruginosa PAOl and use in reconstitution and definition of the permeability barrier. Journal of Bacteriology 136, 381-390. 
Ingram, J. M., Cheng, K.-J. \& Costerston, J. W (1973). Alkaline phosphatase of Pseudomonas aeruginosa: the mechanism of secretion and release of the enzyme from whole cells. Canadian Journal of Microbiology 19, 1407-1415.

LAW, J. H. \& SlePeCKY, R. A. (1961). Assay of poly- $\beta$ hydroxybutyric acid. Journal of Bacteriology 82, 3336.

Lugtenberg, B. \& VAN AlPhen, L. (1983). Molecular architecture and functioning of the outer membrane of Escherichia coli and other gram-negative bacteria. Biochimica et biophysica acta 737, 51-115.

Maizel, J. V., JR (1971). Polyacrylamide gel electrophoresis of viral proteins. Methods in Virology 5, 179-246.

NeU, H. C. \& Heppel, L. A. (1965). The release of enzymes from Escherichia coli by osmotic shock and during the formation of spheroplasts. Journal of Biological Chemistry 240, 3685-3692.

ORDoRfF, P. E. \& DWorkin, M. (1980). Separation and properties of the cytoplasmic and outer membranes of vegetative cells of Myxococcus xanthus. Journal of Bacteriology 141, 914-927.

Osborn, M. J. \& WU, H. C. P. (1980). Proteins of the outer membrane of gram-negative bacteria. Annual Reriew of Microbiology 34, 369-422.

Osborn, M. J., Gander, J. E., Parisı, E. \& Carson, J. (1972). Mechanism of assembly of the outer membrane of Salmonella typhimurium. Journal of Biological Chemistry 247, 3962-3972.

Poirier, T. P. \& HolT, S. C. (1983a). Acid and alkaline phosphatases of Capnocytophaga species. I. Production and cytological localization of the enzymes. Canadian Journal of Microbiology 29, 1350 1360 .

Poirier, T. P. \& Holt, S. C. (1983b). Acid and alkaline phosphatases of Capnocytophaga species. III. The relationship of the enzymes to the cell wall. Canadian Journal of Microbiology 29, 1369-1381.

PoOLE, K. \& Hancock, R. E. W. (1983). Secretion of alkaline phosphatase and phospholipase $\mathrm{C}$ in Pseudomonas aeruginosa is specific and does not involve an increase in outer membrane permeability. FEMS Microbiology Letters 16, 25-29.
Pooley, H. M., Porres-Juan, J. M. \& Shockman, G. D. (1970). Dissociation of an autolytic enzymecell wall complex by treatment with unusually high concentration of salt. Biochemical and Biophysical Research Communications 38, 1134-1140.

ReICHENBACH, H. (1981). Taxonomy of the gliding bacteria. Annual Review of Microbiology 35, 339-364.

REICHENBACH, H. \& DWORKIN, M. (1981). The order Cytophagales (with addenda on the genera Herpetosiphon, Saprospira, and Flexithrix). In The Prokaryotes, pp. 356-379. Edited by M. P. Starr, H. Stolp, H. G. Truper, A. Balows \& H. G. Schlegel. New York: Springer Verlag.

Silhavy, T. J., Benson, S. A. \& EmR, S. D. (1983). Mechanism of protein localization. Microbiological Reviews 47, 313-344.

VON TIGERSTROM, R. G. (1980). Extracellular nucleases of Lysobacter enzymogenes: production of the enzymes and purification and characterization of an endonuclease. Canadian Journal of Microbiology 26, 1029-1037.

VON TIGERSTROM, R. G. (1981). Extracellular nucleases of Lysobacter enzymogenes: purification and characterization of a ribonuclease. Canadian Journal of Microbiology 27, 1080-1086.

von Tigerstrom, R. G. (1983). The effect of magnesium and manganese ion concentrations and medium composition on the production of extracellular enzymes by Lysobacter enzymogenes. Journal of General Microbiology 129, 2293-2299.

von Tigerstrom, R. G. (1984). Production of two phosphatases by Lysobacter enzymogenes and purification and characterization of the extracellular enzyme. Applied and Environmental Microbiology 47, 693-698.

Voelz, H. \& Ortigoza, R. O. (1968). Cytochemistry of phosphatase in Myxococcus xanthus. Journal of Bacteriology 96, 1357-1365.

WhITAKeR, D. R. (1970). The $\alpha$-lytic protease of a myxobacterium. Methods in Enzymology 19, 599613. 